\title{
Exploring Low-Carbon Bus Options for Urban BRT Systems: The Case of Amman
}

\author{
Rana Imam \\ The University of Jordan \\ Seong-Cheol Kang and Diana Quezada \\ Global Green Growth Institute
}

\begin{abstract}
Being able to provide high-quality, metro-like transit service at a fraction of the cost of other options, bus rapid transit (BRT) has been viewed as one of the most cost-effective public mass transport systems suitable for urban areas. Since significant amounts of greenhouse gas (GHG) and air pollutant emissions are attributed to the transport sector, deploying low-carbon buses for BRT systems should be of high priority. With a view to promoting low-carbon buses instead of diesel buses for a BRT system currently being planned in Amman, Jordan, this paper evaluates several low-carbon bus options-hybrid, plug-in hybrid, opportunity charging, trolleybus, and battery electric bus-against the baseline case of diesel buses. While low-carbon buses reduce GHG and air pollutant emissions often considerably, they usually require higher upfront capital costs and additional infrastructure investments. On the other hand, they tend to incur lower energy and maintenance costs and have a longer lifetime, particularly battery electric buses. All these advantages and disadvantages are included in the assessment of low-carbon bus options relative to diesel buses. For the trunk routes of the Amman BRT, the analysis shows that the opportunity charging bus can be the most appealing option, having a positive internal rate of return (IRR) for the incremental investment costs. For the feeder routes, both low-carbon bus options considered, hybrid and battery electric, do not result in a positive IRR. Nevertheless, the battery electric bus is found to be a comparatively better option than the hybrid bus. A sensitivity analysis was conducted for both trunk and feeder routes to examine the variability of several parameters used in the study, such as capital expenditures, electricity price, and diesel price. The results show that IRR could increase favorably under certain conditions.
\end{abstract}

Keywords: Bus rapid transit, low-carbon bus, greenhouse gases, air pollutants, sustainable transport

(C) 2020 Rana Imam, Seong-Cheol Kand and Diana Quezada

https//doi.org/10.5038/2375-0901.22.1.4

ISSN: 1077-291X | Licenced under Creative Commons License Attribution - Noncommercial 4.0

The Journal of Public Transportation is published by the Center for Urban Transportation Research at the University of South Florida 


\section{Introduction}

A growing number of private vehicles is a common challenge to many cities around the world. To mitigate negative externalities associated with the heavy use of private vehicles, such as traffic congestion, air pollution, and large fuel consumption, cities have implemented or are contemplating public mass transit systems, aiming for a significant modal shift from private vehicles. One of such public mass transit systems is bus rapid transit (BRT), a high-quality bus-based transit system that delivers fast, comfortable, and cost-effective urban mobility through the provision of segregated right-of-way infrastructure, rapid and frequent operations, and excellent marketing and customer service (Wright and Hook 2007). Since its early implementation in the 1970s, BRT has become increasingly recognized as one of the most cost-effective solutions to providing mobility services in urban areas, offering high-quality, metro-like transit service at a fraction of the cost of other options (Wright 2011).

The transport sector overall consumes more than half of the global liquid fossil fuels, emits nearly a quarter of the world's energy-related carbon dioxide $\left(\mathrm{CO}_{2}\right)$, and generates more than $80 \%$ of the air pollution in the cities of developing countries (Dalkmann and Sakamoto 2011). Moreover, $\mathrm{CO}_{2}$ emissions from transport could grow to 1.5 to 2.4 times 2010 levels by 2050 (International Transport Forum 2012). These $\mathrm{CO}_{2}$ and air pollutant emissions are primarily ascribed to the use of fossil-based fuels, mainly gasoline and diesel, by internal combustion engine vehicles. Most of the current BRT buses worldwide likewise use fuels of fossil origin, either diesel or compressed natural gas (CNG). Therefore, many BRT systems today are not immune from being blamed for contributing to global warming and deteriorating urban air quality even though their emissions per user are low compared to passenger vehicles.

Meanwhile, vehicles with low-carbon technologies such as plug-in hybrid, electric, and fuel cell have emerged and their competitiveness against vehicles with conventional internal combustion engines is improving as technology prices fall. For instance, price parity between electric and gasoline four-wheel passenger vehicles could occur around 2025 when the cost of a lithium-ion battery pack is expected to fall below USD 100/kWh (Global Green Growth Institute 2019), and this might happen even sooner. The prices of low-end electric motorcycles with a lead-acid battery are already on a par with those of gasoline motorcycles in some developing countries. Buses will not be an exception to this trend. In 2018, electric and fossil fuel buses in the global bus fleet numbered about 0.5 and 2.5 million, respectively, with most of the electric buses running in China (IzadiNajafabadi 2018). Electric buses are forecast to grow their volume to about 1.2 million in 2025, amounting to 75\% of the fossil fuel bus fleet at that time, a significant uptake from 2018.

Unlike light-duty vehicles, electric and fossil fuel buses still demonstrate a relatively large upfront cost differential. However, given the rapid technological transformation taking place and the lock-in effect that the bus technology chosen now will last for 20 years or so, it is prudent and forward-looking to explore low-carbon bus options for urban BRT systems, especially in their planning stage. This paper presents such an exploration for a BRT system in Amman, Jordan.

The next section of the paper reviews the literature on assessing low-carbon bus options against conventional buses to place the study in perspective. The third section explains the evaluation framework used to compare different low-carbon bus options for BRT systems. The fourth section identifies the most suitable low-carbon bus option for the Amman BRT based on the evaluation framework. Finally, some concluding thoughts are provided in the last section. 


\section{Literature on Assessing Low-Carbon Bus Options}

Various studies to compare low-carbon bus options against diesel buses have been performed. The scope of these studies ranges from energy use efficiency (Transportation Research Board 2011), technical performance (Gao, Jin, and Lu 2008), and financial viability (Clark, Zhen, and Wayne 2009; Bloomberg New Energy Finance 2018) to environmental impact (Lajunen 2014).

A study from the Inter-American Development Bank (IDB) tested low-carbon buses in Bogota, Rio de Janeiro, Sao Paulo, and Santiago and showed that the use of hybrid buses reduced local emissions by $60-80 \%$ on average, along with a $30 \%$ reduction in fuel usage, whereas electric buses had zero local emissions and offered up to a 77\% reduction in energy consumption (IDB 2013). Moreover, the life-cycle economic analysis revealed that hybrid and electric buses would reduce overall costs to cities and operators in the long term.

Topal and Nakir (2018) conducted a total cost of ownership-based analysis to compare the economic feasibility of diesel, CNG, and electric buses for the public transport system in the city of Istanbul. This study acknowledged that the biggest challenge for introducing low-carbon buses was their high upfront costs compared to conventional diesel buses. However, it demonstrated that despite the high initial costs, amortization points in electric buses could be caught because of low operating costs.

Recognizing that the sustainability of BRT systems would depend critically on the energy source, fuel type and quality, vehicle technology, and the infrastructure available, the International Council on Clean Transportation (ICCT) carried out a cost-benefit analysis of different clean technology options for BRT buses in Nairobi, Kampala, and Addis Ababa, taking into account the local situation in each of the three cities. The analysis revealed that the selection of any of the advanced BRT technology choices, including plug-in hybrid buses and trolleybuses, would result in significant emissions reductions at a modest additional cost over a Euro III diesel baseline bus (ICCT 2012).

Mukhopadhyay (2017) investigated the decarbonization potential of promoting a BRT system as a mode of public transport in Malaysia. The study compared the reduction in $\mathrm{CO}_{2}$ emissions or equivalent reductions from various BRT and feeder system scenarios that used different types of fuels such as diesel, CNG, and electricity. While the study assessed the greenhouse gas (GHG) emissions of the BRT infrastructure development along its life cycle, it did not estimate the potential costs of emissions reductions from alternative fuel buses.

Chile's Ministry of Transport conducted a financial assessment for replacing $45 \%$ of the existing bus fleet for the Transantiago BRT System, equivalent to 2,970 diesel buses, with low-carbon buses at a cost of USD 500 million. This study supported the decision of the latest bus tender in the country and also proposed new business models related to the procurement and operation of low-carbon buses (Global Mass Transit 2017).

\section{Framework for Comparison of Low-Carbon Bus Options}

Compared to diesel buses, low-carbon buses have the advantage of producing less GHG and air pollutant emissions. Some of those buses also have less fuel and maintenance costs because they are more energy efficient and their vehicle structures are simpler. These advantages, however, often come with higher vehicle costs and additional infrastructure requirements needed to operate those buses. This section describes how GHG and air pollutant emissions were calculated and how low-carbon bus options were compared with the baseline case of diesel buses through financial and economic appraisals. 


\section{GHG and Air Pollutant Emissions}

Among greenhouse gases included under the United Nations Framework Convention on Climate Change (UNFCCC), only carbon dioxide $\left(\mathrm{CO}_{2}\right)$, methane $\left(\mathrm{CH}_{4}\right)$, and nitrous oxide $\left(\mathrm{N}_{2} \mathrm{O}\right)$ are relevant to the transport sector. However, $\mathrm{N}_{2} \mathrm{O}$ emissions calculated by the UNFCCC methodologies for the transport sector are usually marginal, so they were excluded in the analysis framework of this paper.

The amount of $\mathrm{CO}_{2}$ emissions generated by fuel consumption was calculated through equation (1):

$$
E=F C \times N C V \times E F
$$

where $E$ is the amount of $\mathrm{CO}_{2}$ emissions, $F C$ is the amount of fuel consumption, $N C V$ is the net calorific value of fuel, and $E F$ is the $\mathrm{CO}_{2}$ emission factor of fuel. Obviously, different fuel types have different $N C V$ and $E F$ values. The International Panel on Climate Change (IPCC) also includes $\mathrm{CO}_{2}$ emissions from the use of urea in diesel engine catalysts. The amount of such emissions, however, is small compared to that of $\mathrm{CO}_{2}$ emissions from combustion, so they were not considered in this paper.

Methane $\left(\mathrm{CH}_{4}\right)$ emissions in the transport sector mostly result from the methane slip of vehicles that use gaseous fuels such as CNG and liquefied petroleum gas (LPG). The amount of $\mathrm{CH}_{4}$ emissions may not be large, but it was important to capture them in the analysis because of a high global warming potential of $\mathrm{CH}_{4}$. The emission amount can be determined based on the information given in Delgado and Muncrief (2015).

In addition to the direct GHG emissions described above, there exist indirect upstream GHG emissions most notably from electricity production including transmission and distribution losses. Such emissions can be calculated by the combined margin methodology used in the UNFCCC for electricity grid-connected projects. Indirect GHG emissions also include those generated in the process of fossil fuel extraction, refining, and transport. A standard mark-up factor per fossil fuel type is used to estimate those emissions. Indirect GHG emissions are captured in well-to-wheel (WTW) emissions, while the tank-to-wheel (TTW) emissions include direct GHG emissions only.

Black carbon, part of particulate matter mainly from diesel vehicles, is considered to have more impact on climate warming than $\mathrm{CO}_{2}$ on a mass-equivalent basis. In particular, black carbon has, on average, 2,700 times more global warming potential than $\mathrm{CO}_{2}$ per unit of emission within 20 years and 900 times more within 100 years (Bond et al. 2013). Thus, it was important to include black carbon emissions in this analysis even though the emission amount may be small compared to that of $\mathrm{CO}_{2}$. The GHG impact of black carbon can be determined based on the amount of $\mathrm{PM}_{2.5}$ (particulate matter, fine particles) emissions, the fraction of black carbon in $\mathrm{PM}_{2.5}$ (75\%, Ntziachristos and Samaras 2018), and the global warming potential of black carbon in 100 years (i.e., as the product of the $\mathrm{PM}_{2.5}$ emission amount, $75 \%$, and 900 ).

It was important to consider air pollutants such as $\mathrm{PM}_{2.5}$ and nitrogen oxides $\left(\mathrm{NO}_{\mathrm{x}}\right)$ in the analysis framework because they have a high impact on air quality and therefore on human health. Air pollutants are generated not only by combustion, but also by vehicle tires and brakes. In this paper, only combustion-based air pollutants were examined. The amount of $\mathrm{PM}_{2.5}$ and $\mathrm{NO}_{\mathrm{x}}$ emissions can be calculated based on the emission category of a vehicle and emissions per unit of distance driven.

\section{Financial Appraisal}

In performing a financial assessment for low-carbon bus options compared to the baseline case of diesel buses, only differential costs and benefits were considered through a relative cost-benefit approach. Cost and benefit 
elements not related to bus technologies such as driver salary and fare revenue were assumed constant and excluded from the assessment.

In the context of a relative cost-benefit analysis, capital expenditures (CAPEX) included the incremental investment (i.e., purchase) costs for low-carbon buses compared to diesel buses, the costs of additional infrastructure (e.g., charging stations), and the costs of partial replacement (e.g., batteries). Included in operational expenditures (OPEX) were fuel and maintenance costs that vary according to specific bus technologies. Potential differences in the operational lifetime of bus technologies and in bus availability were also considered in the analysis.

The financial attractiveness of a low-carbon bus option relative to the baseline case of diesel buses was measured by the financial internal rate of return (FIRR), a discount rate that makes the net present value (NPV) of all the cash flows (both positives and negatives) from an investment equal to zero. In other words, FIRR is an $r$ that satisfies equation (2):

$$
N P V=-C_{0}+\sum_{t=1}^{n} \frac{C_{t}}{(1+r)^{t}}=0
$$

where $C_{0}$ is the initial incremental investment costs, $C_{t}$ is the net cash flow during year $t$, and $n$ is the lifetime of the investment. In calculating FIRR, only direct costs and benefits accruing to the bus operator were included.

\section{Economic Appraisal}

Introducing low-carbon buses brings additional benefits to a society particularly from reduced GHG and air pollutant emissions. To capture these co-benefits, monetary values need to be assigned to units of GHG and air pollutants so that abated emissions can be monetized.

Valuating GHG and air pollutants has been a topic of much debate and different studies have assigned different cost values on $\mathrm{CO}_{2}$ and air pollutants. The analysis presented here took a study by the International Monetary Fund (Parry et al. 2014) as a reference. The cost of $\mathrm{CO}_{2}$ is expressed through the social cost of carbon (SCC), an estimate of the economic damages associated with an increase in $\mathrm{CO}_{2}$ emissions. Put differently, it is the monetary value of damages that can be avoided due to $\mathrm{CO}_{2}$ emissions reduction. The costs of air pollutants are estimated by assessing how much additional pollutant emissions at ground level increase the mortality risks of the exposed population. Valuing mortality risks-or more precisely, the value per premature death avoided-is often controversial because it involves adjustment by income per capita for individual countries.

Among various estimates of the SCC, Parry et al. (2014) used USD 35 per tonne for illustrative purposes. In the absence of the country specific SCC for Jordan, this value was also considered in this paper. As for the costs of $\mathrm{PM}_{2.5}$ and $\mathrm{NO}_{x^{\prime}}$, Parry et al. (2014) proposed USD 29,144 and USD 227 per tonne respectively for Jordan. Adjusted by a $3 \%$ discount rate, the estimated costs of GHG and air pollutants for economic appraisal in this paper are shown in Table 1. 
TABLE 1.

Economic Costs of Emissions

\begin{tabular}{|c|c|}
\hline $\begin{array}{c}\text { GHG and Air } \\
\text { Pollutants }\end{array}$ & $\begin{array}{c}\text { Cost (per tonne in } \\
\text { 2017 USD) }\end{array}$ \\
\hline $\mathrm{CO}_{2}$ & 43 \\
\hline $\mathrm{PM}_{2.5}$ & 35,843 \\
\hline $\mathrm{NO}_{\mathrm{x}}$ & 279 \\
\hline
\end{tabular}

Similar to the financial appraisal, the economic attractiveness of a low-carbon bus option was measured by the economic internal rate of return (EIRR), an $r$ that satisfies equation (2) where the values of abated GHG and air pollutant emissions are included as benefits in the net cash flow $C_{t}$ calculations. Therefore, EIRR would be higher than FIRR.

\section{Case Study}

\section{Transport in Amman and Its BRT System}

Amman is a city of more than four million inhabitants and governed by the Greater Amman Municipality (GAM). With its size of about $800 \mathrm{~km}^{2}$, GAM is the largest urban area in Jordan and home to $50 \%$ of Jordan's population. In addition, Amman is surrounded by a number of large cities such as Zarqa, Salt, and Madaba.

According to the Global Ambient Air Pollution Database (WHO 2018), the annual mean of $\mathrm{PM}_{2.5}$ concentrations in Amman was $40 \mu \mathrm{g} / \mathrm{m}^{3}$ (micrograms per cubic meter air) in 2015, which was above the WHO guideline of $10 \mu \mathrm{g} / \mathrm{m}^{3}$ and exceeded the national limit of $15 \mu \mathrm{g} / \mathrm{m}^{3}$. The latest data for $2017 \mathrm{from}$ the same source shows a considerable decrease to $28 \mu \mathrm{g} / \mathrm{m}^{3}$, but still does not reach the national limit. According to Hamasha et al. (2010), the air quality monitoring stations in downtown Amman measured an average concentration of $118 \mu \mathrm{g} / \mathrm{m}^{3}$ for $\mathrm{NO}_{2}$, which alone exceeds the national limit of $100 \mu \mathrm{g} / \mathrm{m}^{3}$ for total nitrogen oxides $\left(\mathrm{NO}_{\mathrm{x}}\right)$. Transport, being a major contributor to GHG emissions, is the prime target for reducing air pollution and achieving sustainable development (Dubey and Gunasekaran 2015). Therefore, given the air quality indicators of Amman, the city would benefit from environmentally friendly transport interventions to reach the set targets of its Intended Nationally Determined Contribution (INDC).

The current level of public transport provision in Amman is poor and suffers from a lack of coordination. Current services are operated by a mixture of large buses, minibuses, service taxis that ply fixed routes, and yellow taxis (Imam 2014). The first three of these transit services do not provide their users with adequate information about routes, frequency of service (or schedules), or service times. Moreover, the minibus and Jitney services operate without designated stops and are simply hailed at any point along their routes. The public transport fleet is composed mostly of smaller vehicles operated by either independent operators or small companies. There is little coordination of these services and no active provision of bus priority measures, integrated ticketing, or travel information.

Passengers experience a poor level of service with long journey times and slow speeds (approximately $15 \mathrm{~km} / \mathrm{h}$ during peak periods), uncomfortable conditions, and a lack of integration between different public transport services. The city's rapid population growth coupled with unplanned urban sprawl has further reduced mobility and accessibility, increased traffic jams, and weakened the insufficient public transport systems. The undesirable negative environmental (both pollution and noise) and safety impacts associated with increased vehicular traffic are also noteworthy. Many existing public transport users aspire to travel by car. However, traffic 
congestion and parking problems are already significant in many parts of the city as evidenced by the average car speed of $30-35 \mathrm{~km} / \mathrm{h}$.

Experiencing traffic growth and urban sprawl, the city of Amman recognized the need for an efficient public transport system and has been developing a BRT network. The municipality is also coordinating with the Ministry of Transport to integrate the Amman BRT with the planned Amman-Zarqa BRT. The Amman BRT running way is a segregated, dedicated two-lane in the median of the right-of-way with lateral platforms to ensure BRT operations are not affected by general traffic flows. The planned system consists of three lines as described below and shown in Figure 1.

- Line 1 (Green Line): The $16-\mathrm{km}$ line connects Swuayleh with Mahatta via Sports City with major service at the University of Jordan and is comprised of 19 bus stops.

- Line 2 (Red Line): The 9-km line connects Sports City with Ras El-Ain via Princess Basma Street and 5th Circle and is comprised of 18 bus stops.

- Line 3 (Blue Line): The 7-km line connects Customs Square with Mahatta via Yarmouk Street and Middle East Square; however, this line has been deferred.

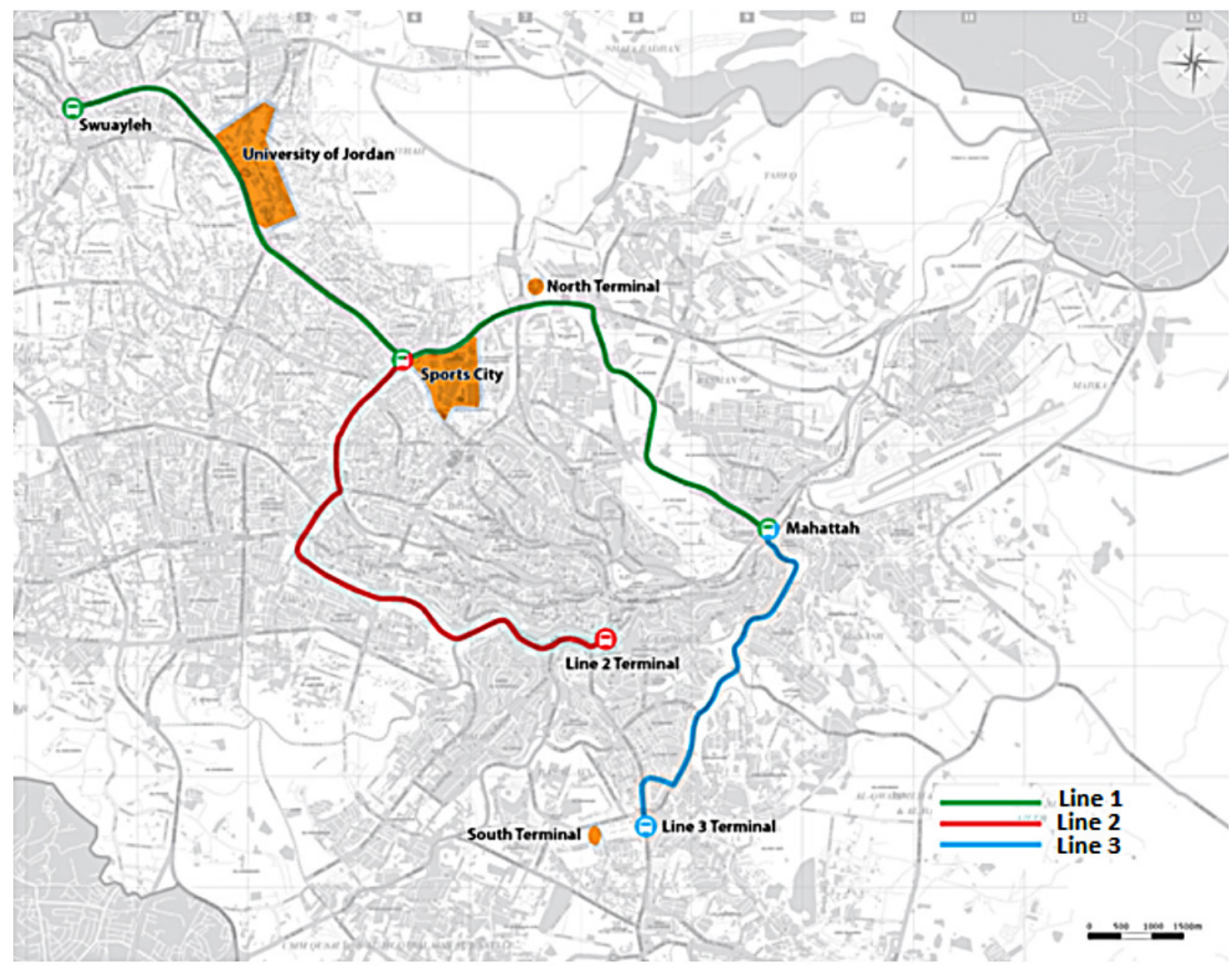

FIGURE 1.

Amman BRT network 
Since the construction of Line 3 has been put on hold, the analysis of trunk routes was based on Lines 1 and 2 only. The service hours during weekdays are planned to be from 6 a.m. until 1 a.m. Weekend service, however, starts at 6 a.m. and ends at midnight. Lines 1 and 2 have a total of 37 stops. Table 2 summarizes the operating conditions of the two BRT lines under construction.

\section{TABLE 2.}

Amman BRT Initial Operating Plan

\begin{tabular}{|l|c|c|}
\hline & Line 1 (Green Line) & Line 2 (Red Line) \\
\hline Line length & $16 \mathrm{~km}$ & $9 \mathrm{~km}$ \\
\hline Headway in peak time (off-peak) & $1.25(1.5) \mathrm{mins}$ & $1.25(1.5) \mathrm{mins}$ \\
\hline Commercial speed & $25 \mathrm{~km} / \mathrm{h}$ & $25 \mathrm{~km} / \mathrm{h}$ \\
\hline Terminal (stand) time & $5 \mathrm{mins}$ & $5 \mathrm{mins}$ \\
\hline Runtime & $38.4 \mathrm{mins}$ & $21.6 \mathrm{mins}$ \\
\hline Cycle time & $86.8 \mathrm{mins}$ & $53.2 \mathrm{mins}$ \\
\hline $\begin{array}{l}\text { Buses/hour/direction in peak time (off- } \\
\text { peak) }\end{array}$ & $48(40)$ & $48(40)$ \\
\hline Number of buses in peak time (off-peak) & $70(58)$ & $43(36)$ \\
\hline Reserve buses in peak time (off-peak) & $7(5.8)$ & $4.3(3.6)$ \\
\hline Peak time vehicle requirement (off-peak) & $77(64)$ & $47(40)$ \\
\hline Passenger capacity of 18-meter bus & 120 & 120 \\
\hline Planning capacity in peak time (off-peak) & $5760(4800)$ pax/hour & $5760(4800)$ pax/hour \\
\hline
\end{tabular}

It is anticipated that more than 150 18-meter articulated diesel-powered buses will serve major points in the city, transporting over 300,000 passengers per day by 2020. Although these diesel buses are expected to meet the Euro $V$ emission standard, intrinsic disadvantages, mainly from the environmental perspective, of fossil fuelbased vehicles would remain. Given the technological advancements and global commitments to curbing climate change, it is worthwhile to consider electric buses as an alternative. The Amman BRT lines are planned on relatively flat terrain without steep road grades that might significantly affect the performance of electric buses.

\section{Evaluation of Low-Carbon Bus Options}

\section{Baseline Bus}

The baseline bus is defined as the bus that would be purchased under a Business as Usual (BAU) scenario. This is not the current bus operating in Jordan but reflects a new bus that would be purchased today in compliance with all legal requirements and in accordance with current standard business practices. Table 3 lists the general parameters for 12-meter feeder and 18-meter trunk buses used in this study, where 330 operating days per year is assumed. 
TABLE 3.

Baseline Bus Parameter

\begin{tabular}{|l|c|c|}
\hline \multicolumn{1}{|c|}{ Parameter } & 12-Meter Bus & 18-Meter Bus \\
\hline Passenger capacity & 80 & 160 \\
\hline Euro emission standard & $\mathrm{IV}$ & $\mathrm{IV}$ \\
\hline Annual distance driven & $60,000 \mathrm{~km}$ & $80,000 \mathrm{~km}$ \\
\hline Average daily driving distance & $182 \mathrm{~km}$ & $242 \mathrm{~km}$ \\
\hline Commercial lifespan of bus & 12 years & 12 years \\
\hline CAPEX & USD 240,000 & USD 400,000 \\
\hline
\end{tabular}

Fuel consumption and emission impacts of the baseline diesel bus are summarized in Table 4.

TABLE 4.

Environmental Impacts of the Baseline Diesel Bus

\begin{tabular}{|l|c|c|}
\hline \multicolumn{1}{|c|}{ Parameter } & 12-Meter Bus & 18-Meter Bus \\
\hline Diesel consumption & $46 \ell / 100 \mathrm{~km}$ & $69 \ell / 100 \mathrm{~km}$ \\
\hline TTW $\mathrm{CO}_{2}$ emissions & $1,237 \mathrm{~g} / \mathrm{km}$ & $1,856 \mathrm{~g} / \mathrm{km}$ \\
\hline WTW including black carbon $\mathrm{CO}_{2 \mathrm{e}}$ emissions & $1,565 \mathrm{~g} / \mathrm{km}$ & $2,338 \mathrm{~g} / \mathrm{km}$ \\
\hline $\mathrm{PM}_{2.5}$ emissions & $0.064 \mathrm{~g} / \mathrm{km}$ & $0.082 \mathrm{~g} / \mathrm{km}$ \\
\hline $\mathrm{NO}_{\times}$emissions & $8.05 \mathrm{~g} / \mathrm{km}$ & $10.23 \mathrm{~g} / \mathrm{km}$ \\
\hline
\end{tabular}

The diesel consumption is the average value of diesel BRT systems around the world (including BRTs of Barranquilla, Bogota, Cali, Guadalajara, Johannesburg, and Zhengzhou operating with air conditioning). The tank-to-wheel (TTW) $\mathrm{CO}_{2}$ emissions were calculated by multiplying the diesel consumption, the density of diesel ( $0.844 \mathrm{~kg} / \ell$, IEA 2005), the net calorific value of diesel ( $43 \mathrm{MJ} / \mathrm{kg}$, IPCC 2006), and the $\mathrm{CO}_{2}$ emission factor of diesel (74.1 $\mathrm{gCO}_{2} / \mathrm{MJ}$, IPCC 2006) - see equation (1). The $\mathrm{PM}_{2.5}$ and $\mathrm{NO}_{x}$ emissions were obtained from COPERT, the EU standard vehicle emissions calculator. The well-to-wheel (WTW) including black carbon $\mathrm{CO}_{2 \mathrm{e}}$ (carbon dioxide equivalent) emissions is the sum of the TTW $\mathrm{CO}_{2}$ emissions, the upstream (well-to-tank) $\mathrm{CO}_{2}$ emissions, and the $\mathrm{CO}_{2}$ equivalent of black carbon. The upstream $\mathrm{CO}_{2}$ emissions were obtained by multiplying the TTW $\mathrm{CO}_{2}$ emissions by the well-to-tank mark-up factor for diesel (23\%, UNFCCC 2014). As for the $\mathrm{CO}_{2}$ equivalent of black carbon, it is the product of the $\mathrm{PM}_{2.5}$ emissions, $75 \%$ (the fraction of black carbon in $\mathrm{PM}_{2.5}$ ), and 900 (the global warming potential of black carbon in 100 years), as previously described.

\section{Trunk Routes}

Currently, 18-meter articulated buses are being considered for the BRT trunk routes. Since commercial experience in operating 18-meter articulated battery electric buses is limited, the low-carbon bus options considered here include hybrid bus, plug-in hybrid bus, opportunity charging bus (based on the TOSA system), and trolleybus. 


\section{GHG and Air Pollutant Emissions}

This study's survey of 10 cities around the world where hybrid buses have been operated shows that the median value of fuel savings compared to diesel buses amounts to $23 \%$. For plug-in hybrid buses, it was assumed that each bus was charged three times per day; twice daily during off-peak operation using a fast charger (duration of each was around 15 minutes) and once during the night through a slow charger. The bus would be equipped with a 60-kWh battery at the minimum. This battery capacity with the proposed recharging would allow an electric driving range of about $60 \mathrm{~km}$, or one-quarter of the total daily driving distance. Based on these assumptions, Table 5 summarizes the amount of diesel consumption per day for the average daily driving distance of $242 \mathrm{~km}$ as shown in Table 3 and emission factors per $\mathrm{km}$ for the 18-meter hybrid and plug-in hybrid buses.

\section{TABLE 5.}

Environmental Impacts of 18-Meter Hybrid and Plug-in Hybrid Buses

\begin{tabular}{|l|c|c|}
\hline \multicolumn{1}{|c|}{ Parameter } & Hybrid Bus & Plug-in Hybrid \\
\hline Diesel consumption per day & $128.6 \ell$ & $95.6 \ell$ \\
\hline TTW $\mathrm{CO}_{2}$ emissions & $1,429 \mathrm{~g} / \mathrm{km}$ & $1,061 \mathrm{~g} / \mathrm{km}$ \\
\hline WTW including black carbon $\mathrm{CO}_{2 \mathrm{e}}$ emissions & $1,800 \mathrm{~g} / \mathrm{km}$ & $1,674 \mathrm{~g} / \mathrm{km}$ \\
\hline PM$_{2.5}$ emissions & $0.063 \mathrm{~g} / \mathrm{km}$ & $0.047 \mathrm{~g} / \mathrm{km}$ \\
\hline $\mathrm{NO}_{x}$ emissions & $7.88 \mathrm{~g} / \mathrm{km}$ & $5.85 \mathrm{~g} / \mathrm{km}$ \\
\hline
\end{tabular}

For the opportunity charging bus and trolleybus, most emissions were zero except WTW emissions from electricity generation. The latter emissions for both buses were assumed to be $1,312 \mathrm{~g} / \mathrm{km}$ based on the vehicle's electricity consumption of $2.3 \mathrm{kWh}$ per km (average value of two cities: Lucerne, Switzerland, and Quito, Ecuador) and the grid emission factor of $0.569 \mathrm{kgCO}_{2} / \mathrm{kWh}$ for Jordan (IGES 2017). Figure 2 compares the annual GHG emissions of the different bus options for the trunk routes.

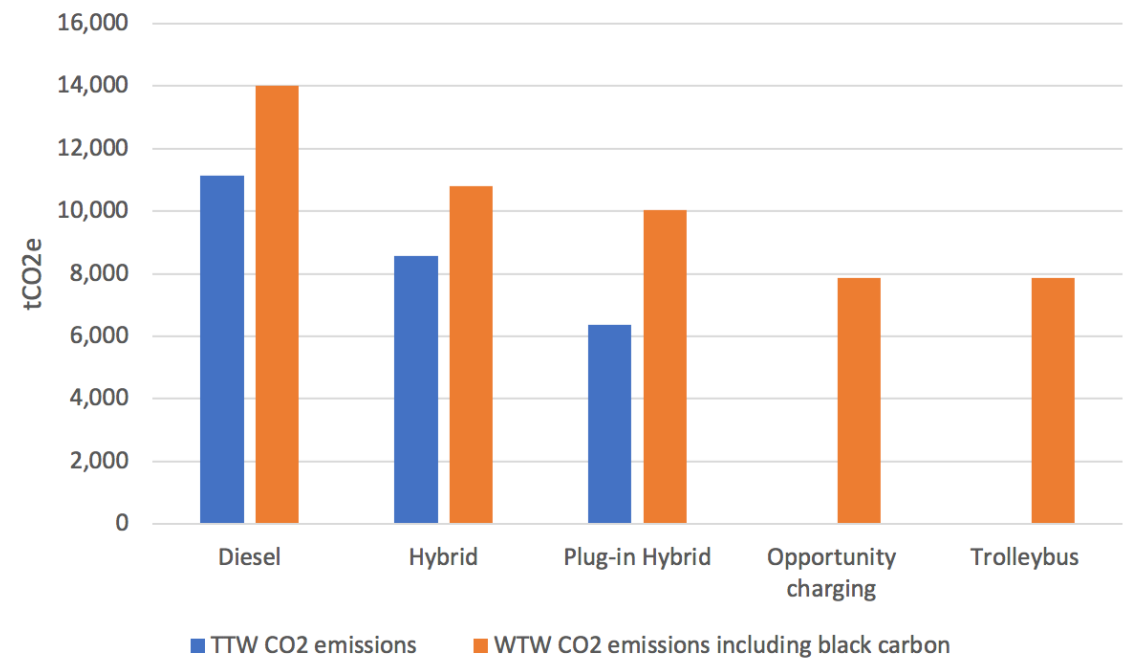

FIGURE 2.

Annual GHG emissions of BRT trunk bus options 
In terms of air pollutant emissions, the two full electric options-opportunity charging bus and trolleybusreduced air pollutants by $100 \%$, whereas the hybrid bus reduced by $23 \%$ and the plug-in hybrid bus by $43 \%$. Table 6 summarizes the expected environmental impacts of the low-carbon bus options compared to diesel buses per annum and over the lifetime of buses, which was assumed to be 12 years for hybrids and 20 years for electric units. Hybrid buses were assumed to have the same lifetime of 12 years as diesel buses because both use a fossil fuel engine as the main propulsion system. It is an assumption often made in (pre-) feasibility studies. In the academic literature, Nordelöf, Romare, and Tivander (2019) and Lajunen and Lipman (2016) used the same lifetime of 12 years for both diesel buses and hybrid buses.

\section{TABLE 6.}

Emissions Reductions (in tonnes) from BAU for BRT Trunk Routes

\begin{tabular}{|l|c|c|c|c|c|c|c|c|}
\hline & $\begin{array}{l}\text { Hybrid, } \\
\text { per Year }\end{array}$ & $\begin{array}{c}\text { Hybrid, } \\
\text { Lifetime }\end{array}$ & $\begin{array}{c}\text { Plug-in } \\
\text { Hybrid, } \\
\text { per Year }\end{array}$ & $\begin{array}{c}\text { Plug-in } \\
\text { Hybrid, } \\
\text { Lifetime }\end{array}$ & $\begin{array}{c}\text { Opportunity } \\
\text { Charge, per } \\
\text { Year }\end{array}$ & $\begin{array}{c}\text { Opportunity } \\
\text { Charge, } \\
\text { Lifetime }\end{array}$ & $\begin{array}{c}\text { Trolley- } \\
\text { bus, per } \\
\text { Year }\end{array}$ & $\begin{array}{c}\text { Trolley- } \\
\text { bus, } \\
\text { Lifetime }\end{array}$ \\
\hline $\begin{array}{l}\text { TTW CO } \\
\text { emissions }\end{array}$ & 2,561 & 30,728 & 4,770 & 57,239 & 11,133 & 222,669 & 11,133 & 222,669 \\
\hline $\begin{array}{l}\text { WTW CO } \\
\text { emissions }\end{array}$ & 3,226 & 38,712 & 3,981 & 47,776 & 6,157 & 123,139 & 6,157 & 123,139 \\
\hline $\begin{array}{l}\text { PM2.5 } \\
\text { emissions }\end{array}$ & 0.1 & 1.4 & 0.2 & 2.5 & 0.5 & 10 & 0.5 & 10 \\
\hline $\begin{array}{l}\text { NOx } \\
\text { emissions }\end{array}$ & 14 & 169 & 26 & 316 & 61 & 1,228 & 61 & 1,228 \\
\hline
\end{tabular}

The TTW GHG emissions reduction of the electric bus options was larger than the WTW emissions reduction due to emissions related to electricity production. WTW emissions also included upstream emissions related to fossil fuel and black carbon emissions. Noise levels of electric bus options were $50 \%$ below diesel buses and around $20 \%$ below diesel for hybrid options.

\section{Financial and Economic Appraisals}

Financial and economic appraisals were based on total cost of ownership, which includes CAPEX of buses and required additional infrastructure as well as OPEX costs of energy and maintenance, while also considering different lifetimes of buses (20 years for opportunity charging bus and trolleybus and 12 years for diesel and hybrid units). The reductions in $\mathrm{GHG}, \mathrm{PM}_{2.5}$, and $\mathrm{NO}_{\mathrm{x}}$ emissions were monetized and included as savings in the economic appraisal. Table 7 summarizes the key results of the financial and economic appraisals. 
TABLE 7.

Financial and Economic Calculations (in 2017 USD) for Trunk Bus Options

\begin{tabular}{|l|c|c|c|c|c|}
\hline & Diesel & Hybrid & $\begin{array}{c}\text { Plug-in } \\
\text { Hybrid }\end{array}$ & $\begin{array}{c}\text { Opportunity } \\
\text { Charge }\end{array}$ & Trolleybus \\
\hline Bus CAPEX & $30,000,000$ & $40,050,000$ & $48,600,000$ & $37,500,000$ & $48,502,203$ \\
\hline Bus infrastructure CAPEX & 0 & 0 & $1,314,000$ & $19,314,000$ & $17,756,000$ \\
\hline Incremental total CAPEX & & $10,050,000$ & $19,914,000$ & $26,814,000$ & $36,258,203$ \\
\hline OPEX savings in year 1 & & 695,106 & 724,560 & 629,400 & 540,620 \\
\hline Economic savings in year 1 & & 146,714 & 182,691 & 299,509 & 299,509 \\
\hline Financial NPV & & $-4,496,176$ & $-12,320,729$ & $-14,003,309$ & $-23,441,410$ \\
\hline FIRR & & $-3.0 \%$ & $-8.3 \%$ & $1.1 \%$ & $-2.0 \%$ \\
\hline EIRR & & $0.2 \%$ & $-6.1 \%$ & $2.9 \%$ & $-0.5 \%$ \\
\hline
\end{tabular}

FIRR and EIRR do not represent the profitability of the total investment for low-carbon buses but do represent the profitability of the incremental investment compared to diesel buses. The net present value (NPV) shows as a discount value if the incremental investment is recovered using the weighted average cost of capital, which was $10.4 \%$ in this study. EIRR includes costs of emissions and is therefore higher than FIRR. The benchmark to use against EIRR would be the social discount rate. The economic total cost of ownership of a low-carbon bus option is lower than that of diesel bus if the associated EIRR is higher than the social discount rate.

From the appraisal results, the opportunity charging system, having the highest EIRR of $2.9 \%$, can be viewed as the most appealing low-carbon bus option for the trunk routes of the Amman BRT. However, the trolleybus option may not be ignored, although having an EIRR close to $0 \%$, due to the fact that CAPEX infrastructure costs could vary widely among cities. To observe how changes in CAPEX and OPEX affect financial appraisal, a sensitivity analysis was conducted with the following changes in parameters:

- Change in CAPEX with a variation of $\pm 20 \%$ for the incremental bus CAPEX and $\pm 50 \%$ for additional infrastructure costs as these costs could differ considerably between cities and depend on specific routes, electricity installations, land cost (an important cost element for trolleybuses due to the land space required for transformers), and local construction costs.

- Change in electricity price with a variation of $\pm 20 \%$.

- Change in diesel price with a variation of no price increase (in real terms) or a $5 \%$ annual price increase (double the BAU parameter).

Figure 3 depicts the impacts of these changes on FIRR. The most promising options are the opportunity charging bus followed by the trolleybus as before. They are most sensitive to reduced CAPEX costs (mainly infrastructure CAPEX), higher than projected diesel price increases, and lower electricity prices, in that order. If economic benefits from reduced emissions are included, the opportunity charging bus option could achieve an EIRR well over $5 \%$. Trolleybus could be another option as it can also result in an acceptable EIRR. 


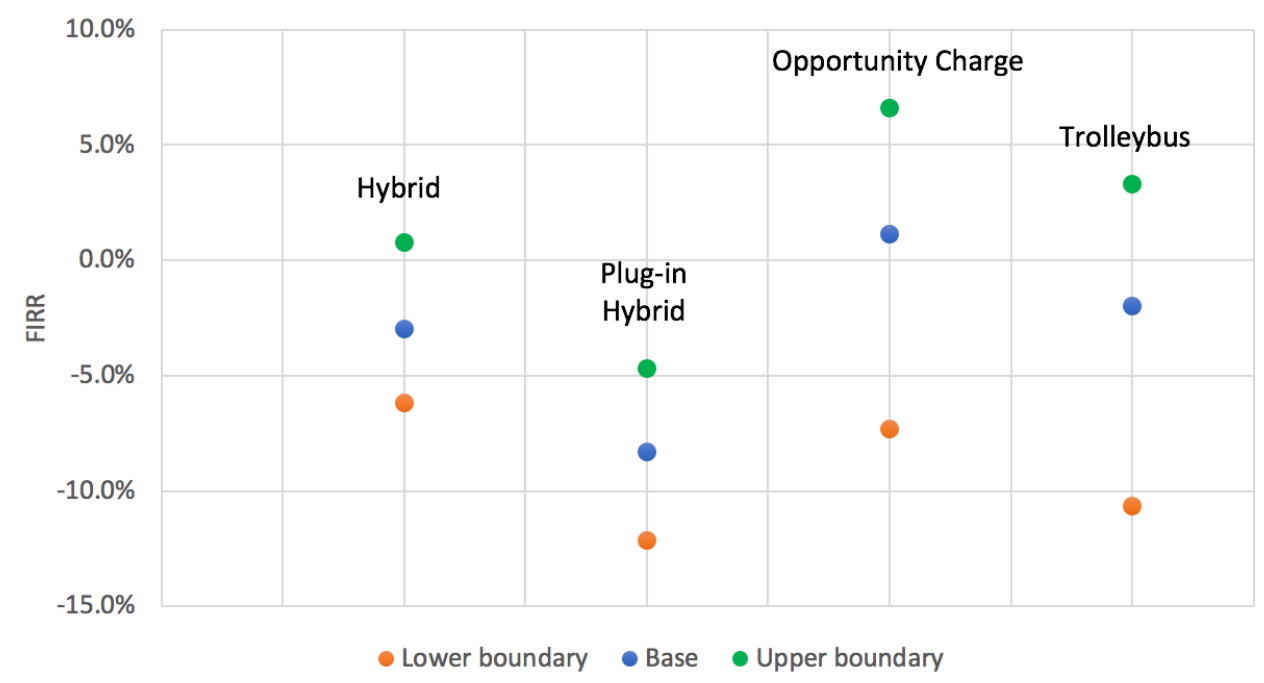

\section{FIGURE 3.}

Sensitivity ranges of FIRR for trunk bus options

\section{Feeder Routes}

The Amman BRT feeder routes are street routes that operate as collection/distribution services for the trunk routes. These routes share the right-of-way with mixed traffic without access to exclusive busways. The analysis for the feeder routes used the total distance traveled by the 50 12-meter diesel buses, required by the operating plan, as a baseline and then compared the baseline with low-carbon bus options for the feeder routes, the hybrid and battery electric buses.

\section{GHG and Air Pollutant Emissions}

Table 8 summarizes the amount of diesel consumption per day for the average daily driving distance of $182 \mathrm{~km}$ as shown in Table 3 and emission factors per $\mathrm{km}$ for the 12-meter hybrid bus.

\section{TABLE 8.}

Environmental Impacts of 12-Meter Hybrid Bus

\begin{tabular}{|l|c|}
\hline \multicolumn{1}{|c|}{ Parameter } & Hybrid Bus \\
\hline Diesel consumption per day & $64.5 \mathrm{l}$ \\
\hline TTW $\mathrm{CO}_{2}$ emissions & $953 \mathrm{~g} / \mathrm{km}$ \\
\hline WTW including black carbon $\mathrm{CO}_{2 \mathrm{e}}$ emissions & $1,205 \mathrm{~g} / \mathrm{km}$ \\
\hline PM2.5 emissions & $0.049 \mathrm{~g} / \mathrm{km}$ \\
\hline NO ${ }_{x}$ emissions & $6.20 \mathrm{~g} / \mathrm{km}$ \\
\hline
\end{tabular}


For the battery electric bus, most emissions were zero, except WTW emissions from electricity generation. The latter emissions were assumed to be $683 \mathrm{~g} / \mathrm{km}$ based on the vehicle's electricity consumption of $1.2 \mathrm{kWh}$ per km (average value of five cities: Zhengzhou, Tainjin, Beijing, and Fuzhou of China, and California, USA) and the grid emission factor of $0.569 \mathrm{kgCO}_{2} / \mathrm{kWh}$ for Jordan (IGES 2017).

Figure 4 compares the annual GHG emissions of the different bus options for the feeder routes. Feeder buses have a lower annual driving distance than trunk buses. Hybrid buses were assumed to have the same lifetime as diesel buses, whereas the lifetime of battery electric buses was assumed to be 16 years.

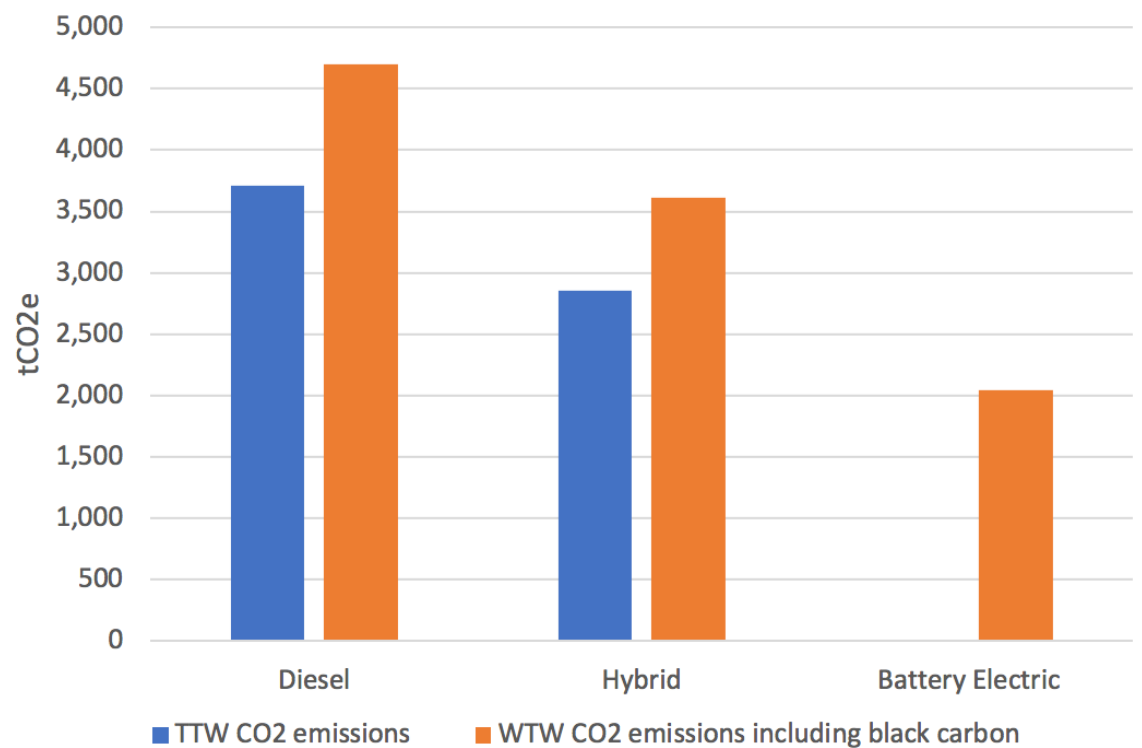

\section{FIGURE 4.}

Annual GHG emissions of BRT feeder bus options

The estimated reductions in GHG and air pollutant emissions from the low-carbon bus options per annum and over the lifetime of buses are given in Table 9. The TTW GHG emissions reduction of battery electric buses was larger than the WTW emissions reduction due to emissions related to electricity production. WTW emissions also included upstream emissions related to fossil fuel and black carbon emissions. Noise levels of battery electric buses were $50 \%$ below diesel buses and around $20 \%$ below diesel for the hybrid option.

\section{TABLE 9.}

Emissions Reductions (in tonnes) from BAU for BRT Feeder Routes

\begin{tabular}{|l|c|c|c|c|}
\hline & $\begin{array}{c}\text { Hybrid, } \\
\text { per Year }\end{array}$ & $\begin{array}{c}\text { Hybrid, } \\
\text { Lifetime }\end{array}$ & $\begin{array}{c}\text { Battery Electric, } \\
\text { per Year }\end{array}$ & $\begin{array}{c}\text { Battery Electric, } \\
\text { Lifetime }\end{array}$ \\
\hline TTW CO 2 emissions & 854 & 10,243 & 3,711 & 59,378 \\
\hline WTW $\mathrm{CO}_{2}$ emissions & 1,080 & 12,956 & 2,646 & 42,335 \\
\hline $\mathrm{PM}_{2.5}$ emissions & 0.04 & 0.5 & 0.2 & 3.1 \\
\hline NOx emissions & 6 & 67 & 24 & 386 \\
\hline
\end{tabular}




\section{Financial and Economic Appraisals}

As with the case of trunk buses, the financial and economic appraisals for the feeder buses were based on total cost of ownership that took into consideration the different lifetimes of the bus options. Table 10 summarizes the main results of the financial and economic appraisals.

\section{TABLE 10.}

Financial and Economic Calculations (in 2017 USD) for Feeder Bus Options

\begin{tabular}{|l|c|c|c|}
\hline & Diesel & Hybrid & Battery Electric \\
\hline Bus CAPEX & $12,000,000$ & $16,020,000$ & $27,338,346$ \\
\hline Bus infrastructure CAPEX & 0 & 0 & $1,550,000$ \\
\hline Incremental total CAPEX & & $4,020,000$ & $16,888,346$ \\
\hline OPEX savings in year 1 & & 231,702 & 611,400 \\
\hline Economic savings in year 1 & & 49,559 & 127,394 \\
\hline Financial NPV & & $-2,105,719$ & $-9,936,287$ \\
\hline FIRR & & $-5.7 \%$ & $-3.7 \%$ \\
\hline EIRR & & $-2.8 \%$ & $-2.0 \%$ \\
\hline
\end{tabular}

Both hybrid and battery electric bus options have negative FIRRs and EIRRs. A sensitivity analysis was carried out for the following changes in parameters:

- Change in CAPEX with a variation of $\pm 20 \%$ for the incremental bus and infrastructure CAPEX as in the case of battery electric buses; variations in infrastructure costs are not as large as in the case of opportunity charging buses or trolleybuses.

- Change in electricity price with a variation of $\pm 20 \%$.

- Change in diesel price with a variation of no price increase (in real terms) or a $5 \%$ annual price increase (double the BAU parameter).

- Change in maintenance costs with a variation of $\pm 10 \%$ for hybrid buses and $50 \%$ less or the same for battery electric buses compared to diesel buses.

- Same annual driving distance of feeder buses as trunk buses.

Figure 5 illustrates the ranges of FIRR that resulted from these changes. The battery electric bus option achieves a slightly positive FIRR under certain conditions. If economic benefits from reduced emissions are captured, its EIRR is expected to increase further. Therefore, the battery electric bus is the preferred low-carbon option for the feeder routes. 


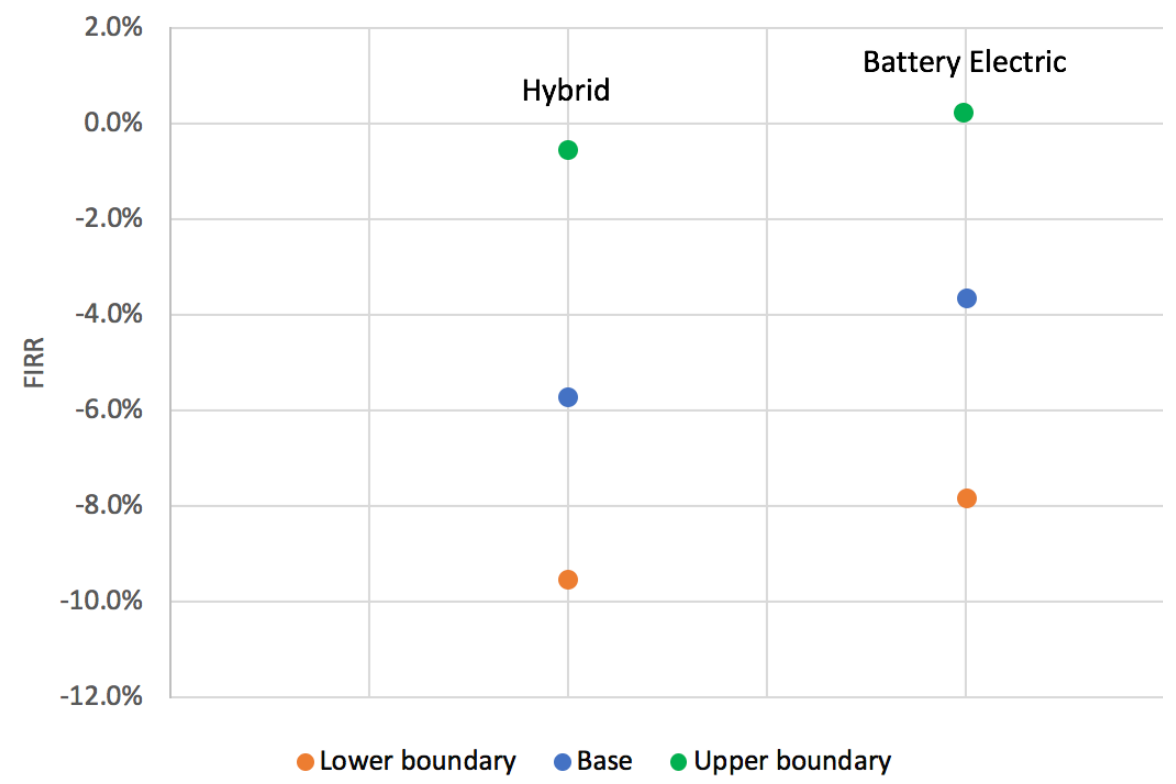

FIGURE 5.

Sensitivity ranges of FIRR for feeder bus options

\section{Conclusions}

With its ability to provide high-quality, metro-like transit service at a fraction of the cost of other options, BRT has been considered one of the most cost-effective public mass transport systems suitable for urban areas. Meanwhile, considering the significant contribution of the transport sector to GHG and air pollutant emissions, electrification of vehicles including buses for BRT systems has emerged as a priority. A relatively large upfront cost differential still exists between electric and fossil fuel buses, unlike light-duty vehicles. However, given the rapid technological transformation taking place and the lock-in effect that the bus technology chosen now will last for 20 years or so, it is prudent and forward-looking to explore low-carbon bus options for urban BRT systems, especially in their planning stage.

The Greater Amman Municipality of Jordan is developing its first BRT system in the city with 18-meter articulated diesel buses. With a view to promoting low-carbon bus options instead of diesel buses for the Amman BRT system, this paper evaluated several low-carbon bus options-hybrid, plug-in hybrid, opportunity charging, trolleybus, and battery electric bus-against the baseline case of diesel buses. While low-carbon buses reduce GHG and air pollutant emissions often considerably, they usually require higher upfront capital costs and additional infrastructure investments. On the other hand, they tend to incur lower energy and maintenance costs and have a longer lifespan, particularly for battery electric buses due to fewer moving parts and less structural vibrations. All these advantages and disadvantages were included in the assessment of lowcarbon bus options relative to diesel buses.

For the trunk routes of the Amman BRT, the analysis showed that the opportunity charging bus could be the most appealing option from financial and economic perspectives. While a positive FIRR and EIRR for the incremental investment costs were achieved, their magnitude was not higher than the weighted average cost of capital in Jordan for both metrics. For the feeder routes, both low-carbon bus options considered, hybrid and battery electric, resulted in a negative FIRR and EIRR. Nevertheless, the battery electric bus was identified as a 
better option than the hybrid bus. In consideration of the variability in several parameters used in the analysis, such as CAPEX, electricity price, and diesel price, a sensitivity analysis was conducted for both trunk and feeder routes. The results showed that FIRR and EIRR could increase favorably under certain conditions.

A range of financial structuring and incentives can improve the financial viability of electric buses for the Amman BRT. The instruments with the largest impact and which have also been used in other cities include bus leasing schemes to reduce the CAPEX differential to bus purchasers and basing the procurement decision on total cost of ownership instead of investment volume, and the electricity company investing in charging and other required infrastructure, thereby reducing initial CAPEX requirements for the bus operator. Preferential electricity pricing for transport and/or the recovery of the charging infrastructure investment not solely from the electricity bill of the transport operator, but also through the general public can also be considered, which might be justifiable due to the positive external impacts of electrified transport and the social function of public transport. Access to climate finance facilities like the Green Climate Fund would also be helpful.

To further reduce the GHG emission impact of electric buses, one recommendation is to use electricity generated by renewable sources, such as through solar photovoltaic systems located near or on the bus depot. This results in zero GHG emission buses from well to wheel and is financially attractive under the current electricity prices in Jordan. The financial competitiveness of electric buses can thereby be significantly improved, while also reaping additional environmental benefits reflected in increased EIRRs. With creative financial structuring, incentives, and renewable technologies, electric bus options can be financially and economically viable and can be run sustainably, thereby reducing emissions and greening urban transport in Amman.

\section{Acknowledgments}

This paper benefited from a study on low-carbon buses for Amman conducted by the Global Green Growth Institute with the technical support of Grütter Consulting.

\section{References}

Bloomberg New Energy Finance. 2018. Electric Buses in Cities - Driving Towards Cleaner Air and Lower $\mathrm{CO}_{2}$.

Bond, T. C., S. J. Doherty, D. W. Fahey, P. M. Forster, et al. 2013. “Bounding the Role of Black Carbon in the Climate System: A Scientific Assessment." Journal of Geophysical Research: Atmospheres 118 (11): 5380 5552. https://doi.org/10.1002/jgrd.50171.

Clark, N. N., F. Zhen, and W. S. Wayne. 2009. Assessment of Hybrid-Electric Transit Bus Technology. Transit Cooperative Research Program (TCRP) Report 132. Transportation Research Board, Federal Transit Administration.

Dalkmann, H., and K. Sakamoto. 2011. "Transport: Investing in Energy and Resource Efficiency." Towards a Green Economy: Pathways to Sustainable Development and Poverty Eradication - A Synthesis for Policy Makers 374-411. United Nations Environment Programme.

Delgado, O., and R. Muncrief. 2015. Assessment of Heavy-Duty Natural Gas Vehicle Emissions: Implications and Policy Recommendations. White Paper. The International Council on Clean Transportation.

Dubey, R., and A. Gunasekaran. 2015. "Sustainable Transportation: An Overview, Framework and Further Research Directions." International Journal of Shipping and Transport Logistics 7 (6): 695-718. doi:10.1504/ IJSTL.2015.072678. 
Exploring Low-Carbon Bus Options for Urban BRT Systems: The Case of Amman

Gao, D., Z. Jin, and Q. Lu. 2008. “Energy Management Strategy Based on Fuzzy Logic for a Fuel Cell Hybrid Bus.” Journal of Power Sources 185 (1): 311-317. doi:10.1016/j.jpowsour.2008.06.083.

Global Green Growth Institute. 2019. G20 Background Paper: Green Growth to Achieve the Paris Agreement.

Global Mass Transit. 2017. "Transantiago Reforms, Chile: Preparing for Version 2.0." Global Mass Transit Report. Accessed November 1, 2019. https://www.globalmasstransit.net/archive.php?id=28637.

Hamasha, K. M., M. S. Almomani, M. Abu-Allaban, and W. P. Arnott. 2010. "Study of Black Carbon Levels in City Centers and Industrial Centers in Jordan." Jordan Journal of Physics 3 (1): 1-8.

IDB (Inter-American Development Bank). 2013. Low-carbon Technologies Can Transform Latin America's Bus Fleets.

ICCT (International Council on Clean Transportation). 2012. Cost and Benefits of Clean Technologies for Bus Rapid Transit (BRT): Summary of Results for Nairobi.

IEA (International Energy Agency). 2005. Energy Statistics Manual.

IGES (Institute for Global Environmental Strategies). 2017. List of Grid Emission Factors.

International Transport Forum. 2012. Transport Outlook 2012: Seamless Transport for Greener Growth.

Imam, R. 2014. "Measuring Public Transport Satisfaction from User Surveys." International Journal of Business and Management 9 (6): 106-114. doi:10.5539/ijbm.v9n6p106.

IPCC (International Panel on Climate Change). 2006. IPCC Guidelines for National Greenhouse Gas Inventories. Edited by S. Eggelston, L. Buendia, K. Miwa, T. Ngara, and K. Tanabe. Institute for Global Environmental Strategies.

Izadi-Najafabadi, A. 2018. "Electrification of Mobility." Presentation at the Innovation \& Sustainability Conference Series 2018.

Lajunen, A. 2014. "Energy Consumption and Cost-Benefit Analysis of Hybrid and Electric City Buses." Transportation Research Part C: Emerging Technologies 38: 1-15. doi:10.1016/j.trc.2013.10.008.

Lajunen, A., and T. Lipman. 2016. "Lifecycle Cost Assessment and Carbon Dioxide Emissions of Diesel, Natural Gas, Hybrid Electric, Fuel Cell Hybrid and Electric Transit Buses." Energy 106 (C): 329-342. doi:10.1016/j. energy.2016.03.075.

Mukhopadhyay, C. 2017. "Public Transport and Bus Rapid Transit as a Tool of Decarbonization in Malaysia." MIR-UTM Malaysia Sustainable Cities Program, Working Paper Series.

Ntziachristos, L., and Z. Samaras. 2018. “Passenger Cars, Light Commercial Trucks, Heavy-Duty Vehicles including Buses and Motorcycles." EMEP/EEA Air Pollutant Emission Inventory Guidebook 2016 - Update July 2018. European Environment Agency.

Nordelöf, A., M. Romare, and J. Tivander. 2019. "Life Cycle Assessment of City Buses Powered by Electricity, Hydrogenated Vegetable Oil or Diesel." Transportation Research Part D: Transport and Environment 75: 211-222. doi:10.1016/j.trd.2019.08.019.

Parry, I. W. H., D. Heine, E. Lis, and S. Li. 2014. Getting Energy Prices Right: From Principle to Practice. International Monetary Fund. 
Topal, O., and I. Nakir. 2018. "Total Cost of Ownsership Based Economic Analysis of Diesel, CNG and Electric Bus Concepts for the Public Transport in Istanbul City." Energies 11 (9). doi:10.3390/en11092369.

Transportation Research Board. 2011. Guidebook for Evaluating Fuel Choices for Post-2010 Transit Bus Procurements. Transit Cooperative Research Program (TCRP) Report 146. Federal Transit Administration.

UNFCCC (United Nations Framework Convention on Climate Change). 2014. Methodological Tool: Upstream Leakage Emissions Associated with Fossil Fuel Use, Version 02.0.

WHO (World Health Organization). 2018. "Ambient (Outdoor) Air Quality Database by Country and City." Accessed May 23, 2020. https://www.who.int/airpollution/data/cities/en/.

Wright, L. 2011. "Bus Rapid Transit: A Review of Recent Advances." In Urban Transport in the Developing World - A Handbook of Policy and Practice, edited by H. Dimitriou and R. Gakenheimer, 421-55. Cheltenham, UK: Edward Elgar Publishing Limited.

Wright, L., and W. Hook, eds. 2007. Bus Rapid Transit Planning Guide. Institute for Transportation and Development Policy, New York.

\section{About the Authors}

Rana Imam (r.imam@ju.edu.jo) is an associate professor in the Department of Civil Engineering at the University of Jordan. She received a PhD in Transportation Engineering from University College London, and an MS and a BE in Civil and Environmental Engineering from the American University of Beirut.

Seong-Cheol Kang (scjkang@gmail.com) is a principal transport specialist at the Global Green Growth Institute. He received a PhD in Systems Engineering from Boston University, dual MS degrees in Transportation and Operations Research from Massachusetts Institute of Technology, and an MS in Transportation Engineering and a BS in Civil Engineering from Seoul National University.

Diana Quezada (diana.quezada@gggi.org) is an analyst at the Global Green Growth Institute. She received an MS in Climate Change, Finance, and Management from Imperial College Business School and a BS in Industrial and Systems Engineering from Instituto Tecnológico y de Estudios Superiores de Monterrey. 